\title{
Erratum
}

\section{Assessment of Vertebral Left Atrial Size and C-reactive Protein in Dogs With Myxomatous Mitral Valve Disease}

\author{
Sun-Hwee Hwang and Kun Ho Song ${ }^{1}$
}

College of Veterinary Medicine, Chungnam National University, Daejeon 34134, South Korea

1) 페이지 정보: J Vet Clin 38(1) : 16-20 (2021)

2) 사사글 삽입 최종본에 대한 안내

2021년 3월 11일 교신 저자 요청으로 해당 논문 p.19에 사사글 추가하였음. 따라서 사사글 추가한 수정본이 최종 본임을 안내함. 